\author{
Yurii Kaparulin \\ Raphael Lemkin Center for Genocide Studies, Department of Public and International \\ Law and Law Enforcement, Kherson State University \\ Kherson \\ https://orcid.org/0000-0001-9099-5766 \\ kaparulin.ksu@gmail.com
}

\title{
The Holocaust in Southern Ukraine: The Response of Survived Jews of Kalinindorf District after the German Occupation
}

\begin{abstract}
Based on archival documents and published and unpublished materials of oral history, the paper offers an overview of the Holocaust in the Kalinindorf district (territories of modern-day Kherson and Mykolaiv Oblast, Ukraine) and the reaction of survived Jews after their return from evacuation and the front. Through particular cases, the paper shows the variants of behaviour and adaptation of Jews to post-war living conditions. The mid-1940s serves as the historical background; it was a period when antisemitic attitudes strengthened in society and in the party leadership. The article indicates how the Jews returned to the pre-war lifestyle in rural areas, but also their rejection of new conditions and changes in the place where they lived. It also investigates the formation of the Jewish community's tradition of commemorative practices in places of mass executions of Jews.
\end{abstract}

Keywords: Holocaust, Ukraine, Kherson region, Jewish agrarian settlements, German occupation.

This is an Open Access article distributed under the terms of the Creative Commons Attribution 3.0 PL License (creativecommons.org/licenses/by/3.0/pl/), which permits redistribution, commercial and non-commercial, provided that the article is properly cited. (c) The Author(s), 2020.

Publisher: Institute of Slavic Studies, Polish Academy of Sciences

Editor-in-chief: Jolanta Sujecka

Conception and academic editing of this issue: Aleksandra Twardowska, Katarzyna Taczyńska 


\section{Introduction}

7 he Holocaust was the biggest genocide in human history. In many

1 European countries, this tragedy had its own regional features that led to radical changes in social life. In particular, in the territories of Soviet Ukraine, the criminal actions of the German occupation authorities and their supporters led to a real humanitarian catastrophe.

In the symbolic space, the Holocaust in Ukraine is still associated with such large-scale operations as the extermination of Jews in Babyn Yar, but it should be understood that there are hundreds more such places of mass extermination. Each of them deserves the most detailed coverage of its story.

The purpose of this article is to study the history of the Holocaust in southern Ukraine. There were unique Jewish agrarian communities in this region. In the circumstances of World War II, the inhabitants of Jewish collective farms found themselves in various life circumstances. We try to trace the most typical of these: evacuation to the east of the Soviet Union, mobilisation to the army and life in the occupied territories. The question of the reaction of Jews returning from evacuation and the front to the Holocaust in the places of their pre-war residence is considered.

Raul Hilberg (1992) showed that members of society in the times of the Holocaust could be divided into three groups: perpetrators, victims and bystanders. These social roles could vary depending on the specific circumstances. Primo Levi called such changes a "grey zone" (Levi, 1989). We follow this approach in the present article.

The source base comprises archival documents, testimonies and memoirs of Jews and their contemporaries. The following methods are used to process the sources: historical-comparative, micro-historical, and system analysis.

A special place belongs to the collection of testimonies from the YahadIn Unum archive, which the author of the article had the opportunity to study during a research internship in Paris.

\section{The First Jewish National District}

In 1807, the first groups of Jewish immigrants arrived in the steppes of Kherson province, the authorities of the Russian Empire having allowed them to create agricultural settlements in southern Ukraine. In the same year, some of those from the Mogilev, Chernihiv and Vitebsk provinces founded the village of Bolshaya Seidemenuha (from the Hebrew sde menuha - "quiet field") within the modern-day Kherson region ("Kalinindorf”, 1988). 
Over the next 100-plus years, the inhabitants of the Jewish settlements took control of the virgin lands of the Kherson region, acquiring and improving farming skills. Despite the prevailing idea in the Russian prerevolutionary historiography that Jewish households were insolvent, at the beginning of the 20th century they managed to achieve significant success, as evidenced by the research of Volodymir Shchukin and Adriy Pavlyuk (Shchukin \& Pavliuk, 2016, p. 369).

According to the census of the population of the Russian Empire, by 1897 Jews made up the majority of the population in the largest centres such as Bolshaya Seidemenuha, Bobrovy Kut, Malaya Seidemenuha and Lvovo (for example, $81.78 \%$ of the population of Bolshaya Seidemenuha 1,284 people) (Pasik \& Khabad, 2009).

During the Ukrainian Revolution of 1917-1921, Jewish settlements suffered massacres, robberies and requisitions. The Russian writer and scriptwriter Viktor Shklovsky, driving through the front-line zones at the time, watched the inhabitants' self-organisation of the defence of the village of Lvovo and neighbouring villages:

We overtake large carts with Jews fleeing from the whites - future pogroms. The Jews drove to the agricultural colony of Lvovo, where they accumulated in such numbers that they weren't beaten... [there were] special customs, Lvovo ones. They go, for example, to trade units in carts, like Makhno. And there were machine guns on the carts, like Makhno had. There is less antisemitism around Lvovo than in other places. (Shklovskiĭ, 1990, pp. 209-210) ${ }^{1}$

In the end, the inhabitants of the settlements supported the authorities that were most loyal to them at that time, i.e. the Soviet authorities.

In the 1920s and 1930s in the Soviet Union, there was an attempt to implement an ambitious social and economic experiment of making the Jewish population agricultural (Kalinindorf, 2019). To this end, tens of thousands of acres of land were allocated in the south of Ukraine and large-scale support was received from foreign organisations. Within a few years from 1924, it was planned to resettle more than 100,000 Jews for the purpose of free farming. One of the main goals of the resettlement was to help overcome the crisis in the social and economic life of the local Jews, to strengthen influence over this part of the population, and to increase international authority with the involvement of financial support.

\footnotetext{
1 “Обгоняем большие телеги с евреями, уходящими от белых - будущих погромов. Ехали евреи в земледельческую колонию Львово, где они скапливались в таком количестве, что их уже там не били... [там] нравы особенные, львовские. Ездят, например, торговать отрядами на тачанках, как Махно. И на тачанках, как у Махно, пулеметы. Вокруг Львово антисемитизма меньше, чем в других местах."
} 
Chairman of the Central Executive Committee of the USSR Mikhail Kalinin noted that:

The life and position of the broad masses of Jewish workers should not be judged by Jewish employees, but by what is being done in numerous cities and towns of Ukraine, Belarus and the western provinces of Soviet Russia. All these surveys confirmed the terrifying poverty of the broadest circles of the Jewish population, $30-40 \%$ of whom have no job... What we are doing in settling working Jews on the land will also play a big role in bringing workers of different nationalities together and eliminating the remnants of the cursed legacy of the past - antisemitism. (Kalinin \& Smidovich, 1927, pp. 13-17) ${ }^{2}$

The first Jewish national region in the Soviet Union, Kalinindorf (named after Kalinin), was created in 1927 on the territory of the modern-day Kherson and Nikolaev regions. Soon, the Stalindorf, Novozlatopol, Freidorf and Larindorf regions were also formed in other areas of Ukraine and Crimea. However, by the end of the 1930s this experiment had not fully achieved its goals, primarily due to collectivisation, political repression, and changes in the foundations of national policies, from integration to assimilation. Also, the residents of Jewish settlements suffered during the Holodomor of 19321933 (Khonihsman, 1994; Korohods'kyĭ, 2013; Tashlaŭ, 2018).

On 5 March 1939 the Central Committee of the Communist Party adopted a resolution "On the Elimination and Transformation of Artificially Created National Areas and Village Councils", which were called centres of "enemies of the people." Unlike most, the Jewish national areas were formally not liquidated. However, they were not restored to their pre-war status after World War II (IAkubova, 2010). Moreover, the topic of Jewish autonomies disappeared from Soviet discourse. It is significant that in the fundamental historical work History of Cities and Villages of the URSR, an article about Kalininske village ${ }^{3}$ contains only a cursory mention of the foundation of the Bolshaya Seidemenuha by Jewish immigrants in 1807 . Not only are no data listed that could at least indirectly indicate what happened during the Holocaust in the region, but also no mention is made of the special national status

\footnotetext{
2 “О жизни и положении широких масс еврейских трудящихся надо судить не по еврейским совслужащим, а по тому, что делается в многочисленных городах и местечках Украины, Белоруссии и Западных губерний РСФСР. Все эти обследования подтвердили факт ужасающей нищеты широчайших кругов еврейского населения, 30-40\% которого не имеет никакого занятия... Проводимое нами мероприятие по землеустройству трудящих евреев сыграет также большую роль в деле сближения трудящихся разных национальностей и изжития остатков проклятого наследия прошлого - антисемитизма." 3 Kalinindorf was renamed Kalininske a few months after its liberation in 1944. After decommunization, in 2016 this village was called Kalynivske.
} 
of the region as one of the main centres of Jewish resettlement in the 1920s and 1930s (Tron'ko, 1982, p. 285). Thus, the topic turned out to be inaccessible to Ukrainian researchers until the collapse of the Soviet Union, leaving quite a few unanswered questions. What was the fate of the Jewish inhabitants of the area? Who managed to escape and return home after the occupation? What was the reaction of the returning Jews to the Holocaust and what was their post-war life like?

Thus, we see that the history of Jewish agrarian culture in the Kherson region goes back to the beginning of the 19th century and is a unique phenomenon in the history of East European Jewry. The study of this topic in Ukraine only became possible with the attainment of the country's independence. Over the past decades, several landmark works have been published in this area. One of the first to raise a num-ber of research questions, in particular about collectivisation and the Holodomor in Jewish agrarian settlements, was Yakov Honigsman (Khonihsman, 1994). The situation of the Jewish population in the broad context of Soviet national policy is shown in the work of Larisa Yakubova (IAkubova, 2003). A significant contribution to the study of the topic was made by Volodymyr Orlyansky (Orlians'kyıı, 2002), who investigated the implementation of the policy of collectivisation towards the Jewish population of southern Ukraine. The economic and cultural adaptation of Jewish agrarians of southern Ukraine was examined by Albert Wenger and Olga Kakovkina (Venher \& Kakovkina, 2014). Works by Mykhailo ZHurba and Victor Dotsenko (Dotsenko, 2014; ZHurba \& Dotsenko, 2005) describe the process of land tenure of Jews in the Soviet Union through the activities of OZET (Rus. Obshchestvo zemleustroistva evreiskykh trudiashchykhsia - Society for Settling Working Jews on the Land). The fundamental source for researchers of the topic was the work of Jonathan Dekel-Chen (2005), dedicated to the history of Jewish agrarians throughout the inter-war period and the beginning of World War II. The activities of the AgroJoint and repressions against employees of an organisation that helped Jewish immigrants were investigated by Michail Mitsel (Mitsel', 2012).

A description of the situation that rural Jews found during the Holocaust is contained in the works of Shchukin (2012), Alexandr Kruglov, Adriey Umansky and Igor Schupak (Kruglov et al., 2016), Mykola Shityuk and Natalia Sugatskaya (Shytiuk \& Suhats'ka, 2008), Yakov Pasik (2015), Michael Gesin (2003), Oleksandr Melnyk (2004) and others. 


\section{The German Occupation and the Extermination of Jews}

The fate of the population of the Jewish collective farms of the Kalinindorf region during World War II was varied. Many inhabitants of military age were mobilised to the Red Army in 1939-1941. Some of them died in battle, some fell into German captivity and were sent to death camps, others were in the partisan movement. In the summer of 1941 anyone who had not been mobilised faced a choice: to evacuate to the eastern territories of the Soviet Union or to stay in territories that would soon become part of the occupation zone. The Soviet leadership did not take any special measures for the organised evacuation of all of the area's inhabitants. Priority was given to party workers and specialists responsible for the export and maintenance of material assets, in particular agricultural machinery. Thus, the decision to evacuate often remained with the inhabitants of the collective farms themselves, among whom, besides the Jews, there were quite a few Ukrainians, Russians and Soviet Germans (according to the 1939 census, of the Kalinindorf District's 19,480 inhabitants, 7,717 were Jews) (Pasik, 2009).

The territories of the Kalinindorf region were seized during 22-28 August 1941. As it will be shown below, most of the Jews who decided to stay in their homes did this intentionally or because they were unable to organise an evacuation on their own due to limited physical and/or financial capabilities.

The first execution of Jews recorded in the materials of the Extraordinary State Commission (ESC) occurred three kilometres from the village of Chervone, where, on 27 August, 150 Jewish refugees from Bessarabia were shot and thrown into a well. In the second half of September, units of the Sonderkommando 10a with the active assistance of the Ukrainian Auxiliary Police and wardens shot and killed about 3,500 Jews (Kruglov et al., 2016, p. 499; Zlochynstva, 1948, pp. 27-29). The local police included representatives of different ethnicities: Ukrainians, Russians and local Germans. It should be noted that this number of victims in the calculations of the ESC is based on the post-war administrative-territorial division. The territories of the pre-war Kalinindorf region became part of the Kherson and Nikolaev regions after liberation. If we were to calculate the total number of victims based on the pre-war borders of the area, their number would be significantly higher (Yahad-In Unum archives, U09, 305, 311, $312,314,320,321,373)$.

The main method of exterminating Jews was by shooting. In the process of preparation, the German command adhered to a certain course of 
action, which involved obtaining data on the number of Jews in the village, discussing the intention to exterminate the Jews with the local authorities, searching for a place for the execution, gathering the Jews in one location and taking them under guard, moving to the place of execution, the actual extermination, organising the distribution of property among employees and local residents (Kaparulin, 2019, p. 37).

The features of the countryside where the Holocaust took place is worth noting. Steppe zones with open spaces tens and hundreds of kilometres long made it hard to escape. It was difficult to find temporary shelter to hide. The places where the victims were gathered together were also atypical; in particular, many executions were carried out near large household wells (Kaparulin, 2019, p. 45).

The extermination of Jews in the steppes of the Kherson region was part of the Nazi plan for taking control of the eastern territories. As Wendy Lower shows, the Nazi policy in Ukraine was based on implementing the ideas of racial and colonial theories. The Nazis believed that Ukraine was inhabited by inferior Slavs who were not able to lead themselves. In addition to enormous natural resources and, as it was believed, a submissive population, Ukraine also fit perfectly into the military plans of the Nazi leaders as an ideal bulwark against Bolshevik Russia. Hitler dreamed of a German colony in Ukraine, a "Garden of Eden" where German settlers, portrayed as "peasant soldiers", would cultivate the land, with weapons at their side to defend themselves from the "Asian hordes". Special attention was paid to the regions where ethnic Germans lived. The territories of the modern-day Kherson region were to become prosperous German lands on the way to the "German Riviera" - Crimea (Lauer, 2010, p. 39-51).

In 1939 there were 1,047 Germans living in Kalinindorf (at this time the area was part of the Mykolaiv Oblast; in 1944 these territories became part of the newly created Kherson Oblast). The descendants of the colonists, like their Jewish neighbours, had been working in the agricultural sector for more than 100 years. These ethnic groups were in the same neighbourhood and in close interconnection. We know that in the 19th century, local Germans helped visiting Jewish colonists to get accustomed to their new conditions and shared the experience of farming with them (Shchukin \& Pavliuk, 2016, p. 210). With the advent of the Nazis, these two ethnic groups were given completely opposite priorities in the policies of the occupying power. Holocaust survivor Rita Rosenberg remembered that in the summer of 1941 she came to her aunt from Kiev, to village No. 6 (the Pioneer collective farm) of the Kalinindorf region, where she found a job: "Aunt took some things to 
the neighbouring village of Zelenyi Hai. Germans from the Volga region lived there and so did my aunt's closest friend - a German, Aunt Marta". ${ }^{4}$ After the execution of all the Jews of the Pioneer collective farm, Rita hid for some time, and then ended up in Zelenyi Hai:

I spent the night in the field, but it was already cold and I decided to go to Aunt Marta to ask for some warm clothes. She replied that she had nothing... I told her that my aunt had been shot. She gave me some rubber boots and something else insignificant. She did not offer to let me stay. I thought it was worth trying to stay in the village and find a job, maybe as a nanny... I found one house and started living there. Later the Germans entered the village. My friend came running to me and said that Aunt Marta had told the Germans that there was a "Jewish child" in one house, and that I must run away. And I ran away not knowing where, into the steppe. (Rozenberg, n.d.) $)^{5}$

This particular case demonstrates a change in the attitude of ethnic Germans towards Jews at the local level under Nazi rule. However, this issue requires a more detailed study, with a search for and involvement of more sources. As can be seen from the recollections below, not all local Germans were completely influenced by the ideology of the occupation authorities; in particular, some of them did not leave with the retreating German units and remained in the houses where evacuated Jews gradually began to return.

In mid-September 1941 the Nazis conducted several operations in which almost the entire Jewish population of the Kalinindorf region was shot. The largest one took place on farms within historical Jewish centres such as Kalinindorf (until 1927 Bolshaya Seidemenuha), Bobtovyi Kut, Sterndorf (until 1929 Malaya Seidemenuha) and Lvovo. We learn about the details of what happened from previously unpublished memoirs of local inhabitants and surviving Jews, as well as materials from trials.

On 17 September 1944, the Military Tribunal of the People's Commissariat of Internal Affairs of the Kherson region, under Art. 54 1a of the Criminal Code of the Ukrainian SSR, sentenced an inhabitant of Kalinindorf, Alexander Zaikyn, to the highest punishment, i.e. execution. According to the sentence, Zaikyn was convicted of collaborationism. He

\footnotetext{
4 “Тетя перевезла некоторые вещи в соседнее село Зеленый Гай. Там жили немцы с Волги и там была близкая подруга моей тети, - немка, тетя Марта."

5 “Я ночевала в поле, но было уже холодно и я решила пойти к тете Марте попросить какие-то теплые вещи. Она ответила, что у нее ничего нет... Я рассказала ей, что тетю расстреляли. Она дала мне резиновые боты и что-то еще незначительное. Она не предложила остаться. Я подумала, что стоит попробовать задержатся в селе и найти работу, может нянечкой... Я нашла один дом и стала там жить. Позже в село зашли немцы. Ко мне прибежала моя подружка и сказала, что тетя Марта сказала немцам, что в одном доме есть «жидовское дитя» и чтобы я убегала. И я убежала не зная куда в степь.”
} 
had joined the police force, where he first worked as a secretary and then was appointed a deputy chief, receiving the rank of non-commissioned officer. According to the materials of the criminal case against Zaikyn, it is clear that he was involved in organising the execution of the Jewish population of Kalinindorf and the subsequent distribution of the murdered Jews' property. In general, the mass shootings as described by Zaikyn match the descriptions by most witnesses of the tragedy:

On 18 September 1941 the Gestapo together with the local German authorities gathered all the inhabitants of Kalinindorf in one place near the collective farm, where the Ukrainians were separated from the Jews. The Ukrainians were allowed to go home, and the Jews were left and shot in an anti-tank ditch not far from the collective farm. The shooting was carried out by the Germans. After the execution of the Jews, on the evening of 18 September, the Germans gathered the men of the village to bury the executed Jews. I also had to bury them. On this day, the 18 th, about 1,500 Jews were shot, killed in two rows over two kilometres. After the execution, for five days, the local German authorities and the police took the Jewish property and all the valuables to the collective farm yard ... (Postwar war crimes, File 1623/0083.00001249) ${ }^{6}$

An inhabitant of the Kalinindorf region, L. Prokopova, was a witness in the case against Zaikyn and noted that he himself had taken the initiative and had been aggressive in identifying Jews and trying to prove Prokopova's Jewish origin in order to get her executed:

In essence, I explained that my husband is Jewish. He was drafted into the Red Army by the mobilisation in 1941. I have one child from him... During the occupation of the Kalinindorf region by the Germans together with the local German authorities, the Jews were shot. I am Ukrainian by nationality and I was left with a paramedic after the execution of the Jews. The womanhater wrote twice to the police and gendarmerie that I was Jewish and had been spared somehow while all the Jews had been shot... Police Chief Shokh and Zaikyn came to my home at night in 1942, both drunk, they woke me up, started calling me a Jewface. Shokh hit me across the face and said that now I will crush your little Jew with one foot. After this bullying they left. After some time, Shokh and Zaikyn called me to the police station, where they interrogated

\footnotetext{
6 “18 сентября 1941 года утром гестаповцы совместно с местной немецкой властью собрали всех жителей Калининдорфа в одном месте возле колхозной фермы где отделили украинцев от евреев. Украинцев распустили по домам, а евреев оставили и расстреляли в противотанковом рву, неподалеку от колхозной фермы. Расстрел провели немцы. После расстрела евреев, вечером 18 сентября, немцы собрали мужчин села закрывать расстрелянных евреев. Мне тоже приходилось зарывать. За этот день 18 числа было расстреляно около 1500 евреев, побиты в два ряда на протяжении двух километров. После расстрела, имущество евреев и все ценности, на протяжении пяти дней, местная немецкая власть и полиция, свозили в колхозный двор...”
} 
me and tried in every possible way to get me shot, but Zaikyn knew very well that I was Ukrainian ... It was only thanks to the help of the head of the collective farm and the chairman of the district council, Kesler, who came to the police to Shokh and Zaikyn, they spoke and said to let me go... (Postwar war crimes, File $1623 / 0083.00001250)^{7}$

Maria Savelevna, who was born in Kalinindorf in 1924, remembered the pre-war life on the local collective farm (kolkhoz), which was called The Way to Socialism, very well. In addition to Jews, there were Ukrainians, Russians and Germans. At the beginning of the occupation, the Jews were informed that they would be sent to Israel and used for harvesting for a time. In mid-September the Jews were ordered to take their most valuable things and transferred to the farm building. From there, they were taken in groups to an anti-tank ditch and shot. According to Mary, the executions lasted two days. There were still some left alive; they fled to hemp thickets, and at night they knocked on the windows of local people and asked for warm clothes. They were gradually caught and also shot. The woman noted that local policemen were involved in organising these operations, two of whom were hanged after the return of the Soviet authorities. One of those hanged was the warden, Mamai. Also, Maria drew attention to the fact that after the war, local Germans who had not taken part in the executions stayed in the village (Yahad-In Unum, U07, 277).

Seraphima Mikhailovna, an inhabitant of Kalininsky (born in 1937), was a child when the war began. Nevertheless, in her memory and from the words of her mother, there were sad moments when she and her father, mother, sister and brother moved to Kherson to seek refuge before the Germans arrived. The father went to the front, while his family managed to hide with his aunt (father's sister) in Kherson. Seraphima remembered the hardships of life in the barn, the time they ate a cake (makukha), and how little brother Misha died and was buried in Kherson.

\footnotetext{
7 "По существу дела я пояснила, что мой муж по национальности еврей. По мобилизации в 1941 году был призван в РККА. От него имею одного ребенка... Во время оккупации Калининдорфского района немцами совместно с местными немецкими властями евреи были расстреляны. По национальности я украинка и меня оставили после расстрела евреев фельдшером. Лихожен дважды писал на меня в полицию и жандармерию, что я еврейка и осталась каким-то путем в то время как всех евреев расстреляли... Начальник полиции Шох и Зайкин в 1942 году ночью приехали ко мне на квартиру, оба пьяные, подняли меня, стали меня обзывать жидовской мордой. Шох бил меня по щекам и говорил, что сейчас твоего жиденка раздавлю одной ногой. После издевательства уехали. Через некоторое время Шох и Зайкин вызвали меня в полицию где допрашивали и всячески стремились только расстрелять, но Зайкин отлично знал, что я украинка... Только благодаря помощи старосты колхоза и председателя районной управы Кеслера, который пришел в полицию к Шоху и Зайкину, что-то переговорил и сказал, чтобы меня отпустили...”
} 
After the liberation of the area in the spring of 1944, the family decided to return home to Kalinindorf. In their house, they came upon Germans living there (Yahad-In Unum, 48, 2196).

An inhabitant of the village of Vysoke, Tatyana Olekseevna, was an eyewitness to the execution of Jews from sections 17, 18 and 19 of the Kalinindorf region. While working in the field, she watched as they were led on foot under escort to the utility well. The woman noted that before the war this well had been used by local people; they drew water using draft power. Tatyana observed a column of Jews who were being shot:

There was a convoy in front and behind. People were carrying bundles. We were scared and hid in haystacks 100 metres from the place of execution. People were shot standing, dressed, and facing the well (shot in the back)... After the execution, we did not go there, not until the well was closed. We were afraid. The houses of the Jews remained, and non-Jews settled in them after the war. (Yahad-In Unum, 48, 2182) ${ }^{8}$

Another local inhabitant, Viktor Mikhailovich, witnessed the same events:

Jews from the 17th section were shot in the field near the well. There was a mound about 50 metres from the well. We walked and saw a column of people leading and there was a cart. There was a German and two policemen. Those on the cart were those who couldn't walk. There were mostly women and children. We went from the trenches to the rink. The guys said people were being led away to be shot. The Jews were put in a line on one side of the well and shot with machine guns. Those who did not fall into the well were thrown down by policemen... The well stood open for a long time. I came here to look for horses, later horses grazed here. No one dug up the bodies. After the war, MTS (tractor station) equipment turned that mound upside down and filled the well. As children, we looked for cartridges and guns. I joined the army in 1952 and this well was still standing. When I returned it was gone and the brigade was gone. It was all levelled, the dugout had been dismantled and there was a field here. (Yahad-In Unum, 48, 2183) ${ }^{9}$

\footnotetext{
8 “Спереду і позаду був конвой. Люди несли вузлики. Ми злякалися та сховалися у стогах сіна метрів за 100 від місця розстрілу. Людей розстрілювали стоячи, одягнених, обличчям до колодязя (стріляли у спину)... Після розстрілу ми туди не ходили, тільки коли колодязь закрили. Ми баялися. Дома євреїв лишилися і після війни у них поселилися не євреї.”

9 “В полі біля колодязя розстріляли євреїв з $17 і$ ділянки. В метрах 50ти від колодязя був курган. Ми гуляли і побачили, як ведуть колону людей і їде одна підвода. Був німець та два поліцаї. На підводі були ті хто не міг йти. Йшли в основному жінки та діти. Ми з окопів перейшли до скирди. Хлопці сказали, що людей ведуть на розстріл. Євреїв поставили в шеренгу з одного боку колодязя та розстріляли з автоматів. Тих хто не впав у колодязь скидали поліцаї... Після війни, технікою МТС, перегорнули той курган та засипали колодязь. Ми як діти шукали та знаходили патрони і нагани. Я пішов до армії у 1952 році і цей колодязь ще стояв. Коли я повернувся його вже не було і бригади не стало. Все розрівняли, землянку розібрали і стало тут поле."
} 
On 27 August 1941 Sterndorf was occupied by German troops. On 17 September 1941 the Nazis and their accomplices shot the entire Jewish population of the village. The bodies of the executed were buried in a silo pit located 100 metres from the collective farm office ("Venok na mogily muchenikov", 2003, p. 526).

As a child, Maria Evdokimovna (born in 1931) remembered how a column of Jews from Sterndorf was led away to be shot: "The Germans almost took me when they were leading away the Jews, because our house was on the edge of the village. They killed everyone in one day" (Yahad-In Unum, U07, 276)..$^{10}$

Maria Semenovna, who moved to Sterndorf in 1937, recalled that during the days of the shooting, non-Jews were taken to the steppe and only allowed to return a week later:

We were loaded onto carts and transported seven kilometres away for a week. We had a dugout and we roamed around. Nobody guarded us and we worked there. We were only allowed to return after a week. The houses had been looted, the windows were broken. The Jews were driven to the neighbouring village of Kalinindorf. There was a utility pit where there was a silo for cows. They cleaned it out. People said that the Jews were stripped to their underwear and shot. Told to fall to their knees and shot from behind. There were people who fell wounded and scared. They buried them alive. (Yahad-In Unum, U07, 275) ${ }^{11}$

On 16 September 1941 in Bobrovyi Kut, all the Jews were driven into the courtyard of the creamery, and then they were taken in the direction of Snigirevka, supposedly for dispatch to Germany. However, they were actually driven into the steppe to an old, large and very deep abandoned well. The situation described by eyewitnesses seems rather chaotic. On that day, people were shot or forced to jump into the well: "One strong old man put his hands on the policeman and jumped into the well with him... 13-14-year-old boy Gezia Zaslavsky spat in the face of the gendarme attacking him and rushed into the 20-fathom depth" (Pasik, 2015). ${ }^{12}$

10 “Мене ледь німці не забрали, коли вели євреїв, тому, що наш дім був край села. Перебили всіх за один день."

11 “Нас погрузили на подводы и вывезли на неделю километров за семь. У нас была землянка и мы там кочевали. Нас никто не охранял и мы там работали. Разрешили вернутся только через неделю. Дома были разграблены, окна разбиты. Евреев угнали в соседнее село Калининское. Там была хозяйственная яма, где был силос для коров. Ее вычистили. Люди рассказывали, что евреев раздевали до белья и расстреливали. Ставили на колени и стреляли сзади. Были люди которые падали раненые и перепуганные. Закапывали и живьем."

12 “Какой-то крепкий старик обхватил руками полицая и вместе с ним прыгнул в колодец... 13-14-летний мальчик Гезя Заславский плюнул в лицо наступавшего на него жандарма и 
Such a situation could arise when a large number of people was gathered together, which was not allowed in other parts of the area, where they were shot in separate groups.

By an act of 4 October 1944, the assistance commission of the Bobrovyi Kut village council for identifying and investigating the atrocities of the Nazi invaders and their accomplices inspected the scene of the massacre and established that three kilometres to the north of Bobrovyi Kut, in the Evgenyevsky steppe, people's corpses had been thrown into the well. A census of the inhabitants of Bobrovyi Kut found that 917 people had been killed, 717 of them were local inhabitants while 200 came from Bessarabia, their names and surnames are unknown (Pasik, 2015).

Another execution of Jews took place on 18 September 1941 near a well two kilometres from the village of Chkalovo (Yudendorf). A local inhabitant, Maria Markovna, saw how the Jews were led away to be shot in two columns (Yahad-In Unum, U07, 286).

On 24 August 1941 German troops occupied the village of Lvovo, and on 16 September they conducted an operation to destroy the Jewish population. An inhabitant of the village, Nina Dmitrievna, recalled that before the war there had been two collective farms, one of which was predominantly Jewish. Lvovo lay on the banks of the Dnieper, in the place where there was a crossing. Many rich Jews were evacuated, while the poor stayed. The Jews were gathered separately from the rest of the village residents and were divided into two groups: the elderly with older children, and women with small children. They were informed that they would soon be sent to work in Germany. Women had been used for harvesting for some time. Later, the elderly and the children were driven from the village and shot in the back:

We looked from the hill, which was far from the place of execution. The Jews were shot clothed, they stood near the edge and then fell into the gulch. There were almost no things left, because they were poor people... maybe someone took some shoes. On the other side was a cattle burial ground where women and young children were shot. Sometimes we [adults] would dig and find a child's boot... Some Jews returned after the war, one was a foreman and the other a leader, but they all united into one collective farm. They all lived together and shared everything. (Yahad-In Unum, 48, 2198) ${ }^{13}$

бросился в 20-ти саженную глубину.”

13 "Ми дивилися 3 пагорба, що був далеко від місця розстрілу. Євреїв розстрілювали одягненими, вони стояли з краю і потім падали в балку. Речей майже не лишилося, тому, що це були бідні люди... може хтось туфлі якісь взяв. 3 іншого боку був скотомогильник де розстрілювали жінок і маленьких дітей... Бувало дорослими копаємося і знаходитися дитячий чобіток... Після війни деякі євреї поверталися. Один був бригадиром, а інший керівником, але всіх об’єднали в один колгосп. Жили всі разом і всім ділилися.” 
Another inhabitant of Lvovo village, Klaudia Ivanovna, was a schoolgirl by the time of the shootings. Among her school friends, she recalled a Jewish girl, Katya Elfen, whom she offered to hide, but the girl refused and decided to stay with her mother. They both ended up in a column that was taken away to be executed (Yahad-In Unum, 48, 2199).

Lidia Nikolaevna from Lvovo noted that before the war, there were mixed marriages in the village and her brothers had married Jewish women; one of the brothers was shot and their grandfather and grandmother raised their three children. The girl remembered how she and her mother watched a column of Jews passing through the village. In it, they saw her mother's friend, who said that her mother should go and pick up the cow that was shut in the barn (Yahad-In Unum, 48, 2200).

Also, there were other Jewish collective farms and plots in the Kherson region. There were five villages in Skadovsky district, the central of which was Lenindorf. At the beginning of October 1941, 1,190 people were shot there. According to the recollections of local inhabitants, the same pattern of extermination of the Jews was applied there as in the Kalinindorf region (Yahad-In Unum, 48, 2215).

Thus, generally speaking, the memories and oral testimonies of the surviving Jews and local inhabitants presented here confirm previously known facts about the extermination of the Jews in the Kalinindorf region. We can say that all the mass operations took place from mid-September to early October 1941. The property and real estate of the murdered Jews were distributed between local residents and newcomer settlers, mainly local Germans, Ukrainians and Russians. Most local non-Jews were passive observers, unable to prevent the execution of the Jews. Some local inhabitants deliberately began cooperating with the Germans for the purpose of personal gain. After the liberation of the territories of the Kherson region in the spring of 1944, evacuated Jewish families and frontline soldiers began to return there.

\section{The Response to the Holocaust}

The response to the Holocaust is a multi-level issue and, depending on the context, can be viewed from the perspective of the state, society, a group or an individual. The Soviet government's reaction to the Holocaust is considered as a separate problem (Gitelman, 1994, pp. 3-21). For example, at the end of June 1941, the Soviet leadership in Moscow was informed that all the oral and written Nazi propaganda "proceeded under the banner of the struggle against the Jews and the communists" (Al'tman, 2002, pp. 385-386). As Karel C. Berkhoff (David-Fox et al., 2014, p. 88) noted, 
during the war the Kremlin seized Nazi documents that spoke of deadly antisemitism. Along with Soviet intelligence reports, this means that Stalin and his collaborators knew from various sources about the extermination of all Jews and Gypsies by the Nazis.

In the context of the paper's title, response as the concept of a reaction to an action is connected with a person's psychology, especially their emotions. In this case, emotions should be understood not only as the experiencing of a relationship, but also as anything that motivates, organises and directs a person's perception, thinking and actions, and therefore their behaviour as a whole (Maksymenko, 2008, p. 240).

The Jews who decided to evacuate expected difficulties on the way. Many died from diseases and bombings by German aircraft. Some chose the wrong route, ending up in occupied territory in the hands of Nazi or Romanian troops, and were shot far away from home. Thus, only some were able to overcome the hardships of the road and find shelter within the Central Asian republics, in the central regions of Russia and Siberia. The large families of Jewish agrarians were split up, and their members ended up in the front lines, under occupation and as evacuees.

Many people did not learn about the tragic fate of loved ones who remained in the occupied territories until the end of the war. After the liberation of the Kherson region in March 1944, many evacuated Jews decided to return to their native land. The return procedure involved obtaining a call to move from the district party committee. To receive such a document, the residents of the Kalinindorf region sent letters with requests. Along the way, many were interested to hear about the fate of their near and dear who had remained in the occupied territories. Many replies from the authorities reported that the local Jews had been shot.

Natives of Kalinindorf who were serving in the Red Army in 1944 also began to be interested in the fate of their loved ones. Some of them received leave and went to personally visit their native parts.

The response of the surviving Kalinindorf Jews to the Holocaust was varied and, in particular, influenced their decision to return to their homes or search for a new place of residence.

The relationship between the new local Soviet authorities and the evacuees was an important issue. Correspondence between them indicates that in many cases the employees of the communist party's district committee were indifferent to the Jews' desire to return.

According to V. Khanin (2016, p. 39), the period from 1944 was the beginning of a crisis and contradictions that affected both traditional and secular forms of Jewish life in Ukraine. The causes of the crisis included the demographic catastrophe and the terrible loss of Jewish social and 
material resources during the war, as well as the aggravation of "social" antisemitism both during World War II and shortly afterwards. This antisemitism served as the basis for intensifying the efforts of the Ukrainian communist authorities to prevent any revival of Jewish community life and development of its infrastructure (Khanin, 2016). Nevertheless, as noted by Genadii Kostyrchenko, despite the antisemitic mood of the political elite, the authorities did not encourage "plebeian" antisemitism and, fearing "amateur action", severely suppressed it (Kostyrchenko, 2010, p. 142).

In our case, it is significant that soon after liberation the Kalinindorf region was officially renamed Kalininsky, without any attempt to restore the Jewish administration. However, it would be a mistake to assert that Jewish life had completely disappeared from these parts. Despite the difficulties with moving and recovering their property, representatives of several dozen families did in fact return. On the spot, they were faced with the pain of learning of the tragedy that had befallen their relatives and friends, the indifference of the authorities, and meetings with local residents who had participated in the reprisals against their neighbours. All this determined different responses of the returning Jews to the Holocaust.

Members of families separated by the circumstances of the war quite often lost contact for several years. From the autumn of 1941, many Jews from the Kalinindorf region did not know about the fate of their loved ones who had remained in occupied territory. Only after the liberation of the district in 1944 did they get the opportunity to return or make a request to the local authorities in this regard. For example, Peyce Budker from the Reuter-Stern collective farm asked the chairman of the Kalinindorf District Council to inform him about the fate of his relatives and other members of the collective farm, and to send a call for his return home (Kaparulin, 2018, pp. 202-203).

Khaya Siganevich was the mother of many children; at the beginning of the war she decided on a difficult evacuation. After leaving her house, she travelled in a freight car with part of the family from the Kalinindorf station to the rear, to the territory of Bashkiria. After the liberation of the Kherson region in 1944, the family returned home. The former Ukrainian and Russian collective farmers remembered her as a "Jewish mother", they told her the terrible news that her daughter Genia, together with her four sons, had been shot in September 1941, and showed her the place of execution. Khaya stayed on to live in Kalinin until her death in 1948 (Modievskiī, 2006, pp. 83-87).

Boris Miloslavsky was mobilised to the Red Army at the beginning of the war, and his wife Lyuba was evacuated. Most of their relatives remained 
under occupation in Pervomayskoe village in the Kalinindorf district. At the end of the war, Major Boris contacted the district centre and found out that his relatives had been killed during the occupation. The same fate had befallen Lyuba's father. The occupants threw mother Hannah and sisters Eugene and Manya into the well in the 12th section. Lyuba's father Moses, the mother of Bert, sisters Genia and Dusia, brothers Abrash and Boris were all killed. The rural childhood of Lyuba and Boris had passed in these places; however, the old happy memories were now a heavy burden on their souls. Boris and Lyuba could not stay there (Modievskiĭ, 2006, pp. 115-117).

Arkady Weisspapier was born in 1921 in the village of Borovy Kut, where several generations of his relatives had lived and worked before him. For a time, his father ran the collective farm, and his mother worked in the vineyards. Arkady had an older brother, Benyamin, and a younger sister, Basya. In 1939 he graduated with honours from the 10-year school and planned to continue his studies in Odessa. However, in 1938 his father Moses was repressed as a Zionist and an opponent of collectivisation, and then shot (Derzhavnyı̆ arkhiv Khersons'koï oblasti. - R4033. - Op. 5. - Spr. №119. - ark. 3; 96-97; 1477).

Arkady did not know about his father's execution, but linked his refusal of admission to the university with the fact that he was the son of an "enemy of the people". Arkady worked in his village as a tractor driver, and with the outbreak of the war he was drafted into the Red Army. He participated in the defence of Kiev, and was seriously wounded in battle. Then the Soviet troops were surrounded and the Germans captured the hospital with the wounded. Arkady survived, but he was sent to one of the death camps - Sobibor.

Sobibor was a model extermination camp: the head of the SS troops, Heinrich Himmler, Hitler's confidant, came here personally. The rebellion in 1943, the only successful uprising in a death camp in the history of World War II, forced the liquidation of the Sobibor death camp, where hundreds of thousands of people had been brutally killed. Arkady was an active participant in the rebellion. After the escape he joined the partisan detachment of the Brest formation, which in April 1945 joined the Red Army.

In the army, Arkady found out that his brother had been killed at the front, and the Nazis in Bobrovyi Kut had shot his mother, sister and relatives:

When I was in the army, I wrote to my village. I asked to be informed which of my relatives was still alive. I was told that everyone had been killed. And Fanya, my friend, was in the village and they showed her my letter, she wrote to me. 
I then went to her in Artemivsk and a month later we got married. (Kovba \& Prokhorova, 2018) ${ }^{14}$

Despite the fact that Arkady and Fanya decided not to return to Bobrovyi Kut, they kept in touch with the Jews who had returned from the evacuation, and they came to the village for commemoration meetings (Krichevskaia, 2017).

In 1944 a Red Army commander, Grigory Gerchik, was dismissed from the liberated Kalinindorf. Local residents told him how the Germans had tortured and mocked his parents. The father was tied hand and foot, tied to a horse and dragged along the village, and his mother was shot. Fellow villagers said that one of the killers was a local resident from the neighbouring Testament of Ilyich collective farm. Grigory tracked down and trapped him near the house and said that he deserved only death for his actions. Despite the neighbour's request not to commit a lynching, Grigory shot him from a captured Walther. Afterwards Grigory went along the river, where he was detained by the district police. The commander provided his documents and reported to Moscow about the lynching. During several months of the investigation, he did not hide his guilt and as a result continued to serve in a partisan detachment in Latvia, where the end of the war found him (Modievskiĭ, 2006, pp. 121-122).

Emil Chausovsky was evacuated from Bobrovyi Kut with his family. In his memoirs, he noted that when leaving for the evacuation, the family was given a special certificate by the village council. Collective farmers did not have passports then, and the certificate was the only document proving their identity. Late on the night of 12 August 1941, the family set off in a cart on a long journey eastwards. Only old people, women and children remained in the village. All men of military age, except for the sick, were mobilised and most of them, especially the young ones, died in battle. Emil's father was released from military service due to asthma. But in 1942, when the situation at the front was critical, he was drafted into the army and stayed on the front lines until the end of the war.

Two weeks after the departure of the Chausovsky family, Bobrovyi Kut and the entire Kalinindorf region was occupied by German troops. The family learned about the fate of their relatives and fellow Jews who had remained in the village, and the terrible tragedy that happened there, much later from the stories of witnesses and an article by the war

\footnotetext{
14 “Я ще коли був в армії, написав до себе в село. Попросив, щоб мені повідомили, хто 3 моїх родичів ще живий. Мені відповіли, що всі загинули. А Фаня, мій друг, була в селі, і їй показали мого листа, вона мені написала. Я поїхав тоді до неї в Артемівськ і через місяць ми одружилися."
} 
veteran A. Zharov, "The Last Way", in one of the Kherson newspapers. Emil Chausovsky noted that after the war some of the evacuated and frontline soldiers returned to Bobrovyi Kut. Others settled in Kherson, Krivoy Rog, Kharkov and other cities. Some of the returning war veterans whose families had died in Bobrovyi Kut married immigrant women. For them, life continued, and children appeared in mixed families (Chausovskiĭ, 2018).

An inhabitant of Chkalovo village, Elena Nikolaevna, recalled that after the liberation of the village some of the Jews returned there: "Some Jews returned, but they had already died here" (Yahad-In Unum, U07, 288). ${ }^{15}$

Israel and Henia Gribun had four daughters: Anna, Fira, Klara and Sarah. During the evacuation, during the shelling of a German aviation crossing near Lvovo village, their father Israel perished. Despite the difficulties, the family managed to evacuate. After the liberation of the Kherson region, the family decided to return to their native land. Sarah worked as an agronomist in Lvovo village, Fira became head of the kindergarten, Klara was a pioneer leader at the Kalinin school, and Anna became head of the cultural enlightenment department of the Kalinin district executive committee (Modievskiî, 2006, pp. 146-149).

An inhabitant of Zamozhne village (plot No. 33 before the war), Peter Viktorovich, remembered how he took part in cleaning up the local well where Jews had been executed during the war. The remains were moved to boxes and reburied. The well was cleaned at the initiative of Isaac Sovransky, who returned from the front. His wife and children had been shot in the area during the occupation. Subsequently, the well was used for the development of animal husbandry (Yahad-In Unum, 48, 2193).

Daniil Tartakovsky and his parents were evacuated, but in the process they were surrounded in the Krasnodar Territory, where they survived the occupation. After the liberation of the territories by Soviet troops, they decided to return home to the 10th section. After returning, the family found out that the Jews of their village and the whole area had been shot. Relations with some local inhabitants were difficult. Returning Jews were called "non-residents". Once, one of the local collective farmers severely beat up father Daniil, and soon after that they decided to move to the Vinnitsa region (Tartakovskii, n.d.).

Gesele Mazlin from Sterndorf was drafted into the army at the beginning of the war. His mother, wife and child stayed in the village. After demobilisation in 1946, he returned to the village. In his house, he met migrants from Poltava. He learned from the villagers that his whole family had been shot at a trench near the village. At the same time Esther

15 “Некоторые евреи вернулись, но они уже умерли тут." 
Revzin, whose husband had died at the front in 1941, returned to Bobrovyi Kut from the evacuation with her daughter. The widower and widow got married in 1946 and soon they had a son and a daughter (Modievskiŭ, 2003b, pp. 19-22).

Samuel Rukman from Kalinindorf went to the front in 1941. In 1945 he returned to his collective farm, where he found out that his whole family had died at the hands of the Nazis. The man decided to stay in his native land. Three years later, he was elected chairman of the kolkhoz. He continued to live in Kalininsky until his death in 1997 (Modievskiĭ, 2003a, pp. 56-57).

A monument to the victims of the execution was unveiled in 1948 at the site of execution, not far from Kalinindorf. Earlier, in mid-1944, the state of the place of execution of Kalinindorf residents was the subject of correspondence between the famous writer, journalist and public figure, Ilya Ehrenburg and the chairman of the Kherson regional committee of the Communist Party of Ukraine. The reason was a letter Ehrenburg received in 1944 from Major of the Red Army Oxenkrug in which he reported on the local authorities' complete indifference to the issue of doing something with the place of the tragedy (Kaparulin, 2018, pp. 195-199). As a result, in subsequent years, representatives of the Jewish community dealt with the matter themselves.

Ishiya Belenky, an inhabitant of Kalinindorf, was one of the first to return from evacuation. Almost immediately, he began to gather information about the tragedy of the lives of 1,875 people. He began to examine the ditches and wells in Kalininsky and near the villages, in which he found many human remains. At that time, he was chairman of the Kalinindorf Village Council, which covered Sterndorf and the 21 st district. At a trench near Kalinindorf, he saw human bones sticking out of the ground. In addition, Ishiya noticed that cattle grazed at the ditch with the bodies of victims, and a road had been laid across it, along which vehicles moved day and night. He immediately appealed to the district executive committee with a statement about the need to improve the graves and close the road. Not having received support, he gathered teachers and high-school students, and together it took them a few days to put the mass grave, 400 metres long, in order. The road was blocked. Then it was possible to assemble an initiative group, which addressed the issue of improving the place of execution. Letters were sent to different cities where relatives of the victims lived. Over the next three years, Belenky personally travelled around the cities to organise the collection of donations and transfer them to an account in Sberbank (a government bank). As a result of this work, a monument to the victims of the Holocaust in the former Kalinindorf Jewish National 
District was unveiled on 19 September 1948. The monument received an ethnically neutral inscription common in the Soviet Union, in Yiddish and Russian: "Soviet citizens rest here, Kalinin village. 1,875 people: old men, men, women and children were brutally tortured and executed during the period of temporary occupation by the Nazi invaders and their accomplices on 16 September 1941" (Modievskiü, 1999, pp. 38-40). ${ }^{16}$

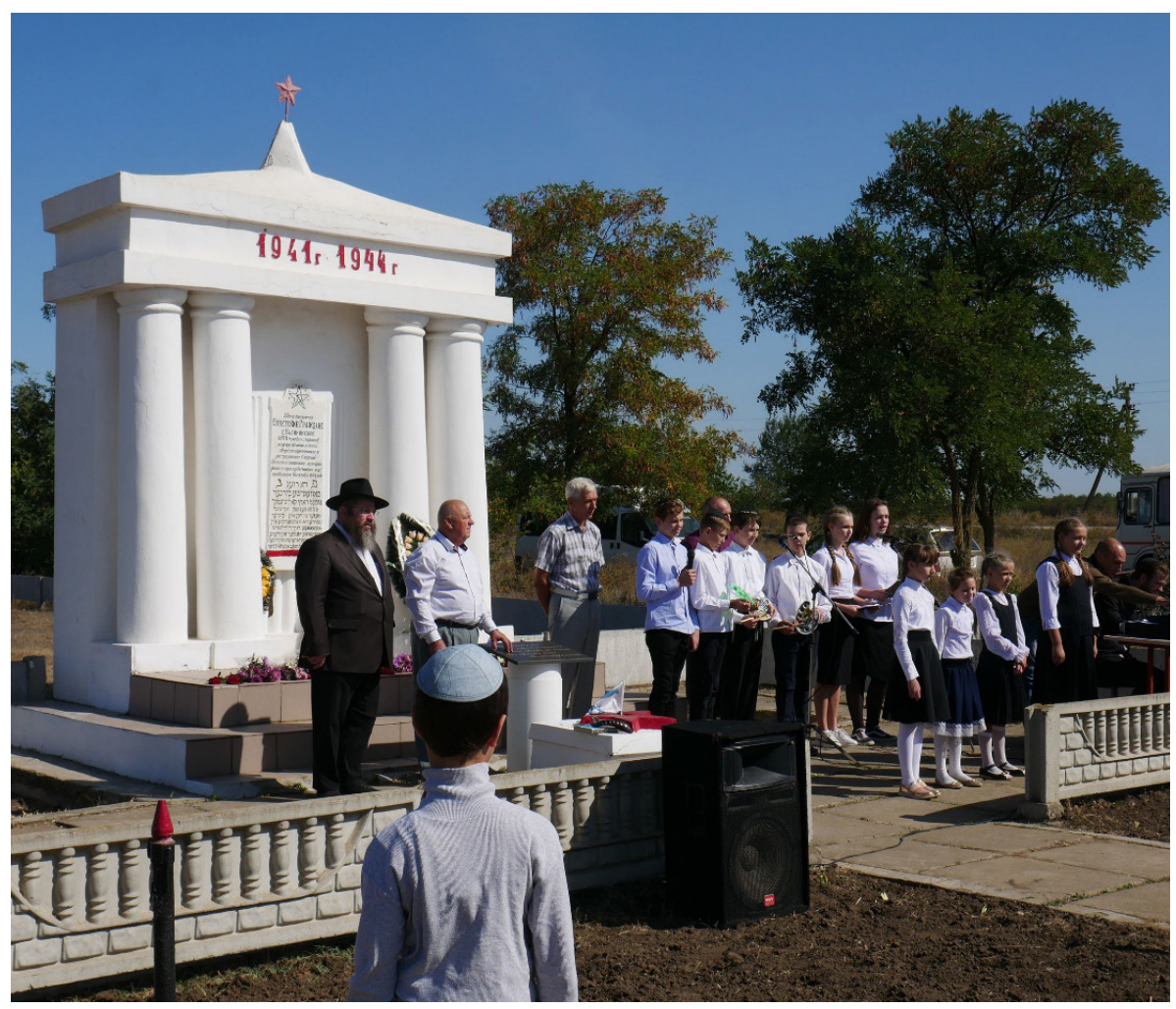

Fig. 1. Memorial Day in Kalynivske, 15 September 2019.

Photo by Yurii Kaparulin

16 “Здесь покоятся советские граждане с. Калининское. 1875 человек стариков, мужчин, женщин и детей зверски замученные и расстрелянные в период временной оккупации немецко-фашистскими захватчиками и их пособниками 16 сентября 1941 года." 


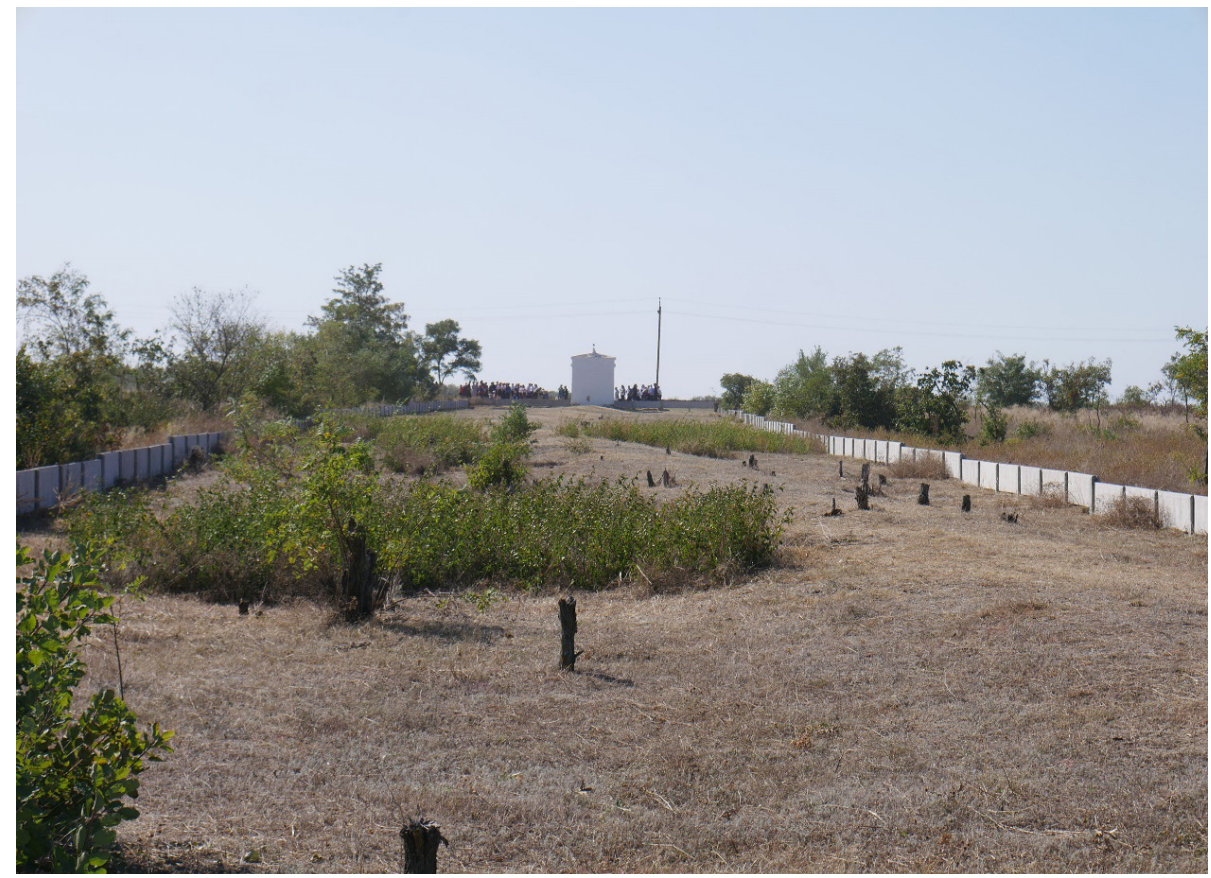

Fig 2. An anti-tank ditch near Kalynivske where local Jews were murdered in September 1941. Photo by Yurii Kaparulin

The more time passed, the more evident the trend towards the universalisation of the victims of war became in the official Soviet policy of memory. Nevertheless, Soviet citizens were able to learn about the targeted extermination of Jews by the Nazis, which reached 6 million people, from Ehrenburg's article in the newspaper Pravda dated 17 December 1944. However, as noted by Arkady Zeltser, in the final period of the war and in the early post-war years, the issue of memorialising the sites of execution of Jews depended on the activity of local Jewish communities, the attitude of local authorities towards the subject of Jewish victims and the interpretation of the party line on this issue (Zeltser, 2018, pp. 122-136).

Thus, several thousand Jews lived in the Jewish agrarian settlements of the Kalinindorf region during World War II. Most of them died from Nazi bullets during September-October 1941. Many Jews were mobilised to the ranks of the Red Army. Not everyone was destined to return from the front. A significant group of the inhabitants of these settlements managed to evacuate to the eastern territories of the Soviet Union.

After the liberation of the territories of the Kherson region in the spring of 1944, the Jews who had survived the Holocaust began to return to 
their homes. With the restoration of the Soviet administration, inquiries began to come in from Red Army soldiers who wanted to know the fate of their relatives who had stayed in the occupied territories. All of them received news of the terrible facts of the extermination of their relatives and neighbours - men, women, children and the elderly.

The response of the surviving Jews to the Holocaust in the Kalinindorf region was varied. Memoirs, documents and investigative cases record instances of lynching and a desire to mark the places of mass graves, condemning the indifference of local authorities towards the tragedy of the local Jews. There were cases of disputes over the appropriation of Jewish property by old and new locals. Some people experienced stress associated with the realisation of the scale of the tragedy or moral pressure from local residents, among whom were former collaborators. These factors forced some Jews to move to other places. There were cases when families or their individual members returned, reconciled themselves to their fate and stayed on to live in these places in subsequent years. People worked on restored collective farms, started new families, gave birth and raised children. Mixed marriages (between Jews and Ukrainians or Jews and Russians), known already in the pre-war period, grew in number (we still do not have accurate statistics of such marriages, which could be the subject of further research). However, the history of this area as a Jewish national region was hushed up over the next several decades in connection with the antisemitic campaign of the Soviet government.

\section{Sources}

Derzhavnyı̆ arkhiv Khersons'koï oblasti. - R4033. - Op. 5. - Spr. №119. - ark. 3; 96-97; 1477.

Postwar war crimes trials related to the Holocaust, United States Holocaust Memorial Museum Archives, Washington, DC. File 1623/0083.00001249; 1623/0083.00001250, 1623/0083.00001277; 1623/0083.00001278, Reel 83, RG-31.018M

Yahad-In Unum archives. Trip No. U07 UK. Witness No. 275 UK. Yahad-In Unum archives. Trip No. U07 UK. Witness No. 276 UK. Yahad-In Unum archives. Trip No. U07 UK. Witness No. 277 UK. Yahad-In Unum archives. Trip No. U07 UK. Witness No. 286 UK. Yahad-In Unum archives. Trip No. U07 UK. Witness No. 288 UK. Yahad-In Unum archives. Trip No. U07 UK. Witness No. 292 UK. Yahad-In Unum archives. Trip No. 48 UK. Witness No. 2182 UK. 
Yahad-In Unum archives. Trip No. 48 UK. Witness No. 2183 UK. Yahad-In Unum archives. Trip No. 48 UK. Witness No. 2193 UK. Yahad-In Unum archives. Trip No. 48 UK. Witness No. 2196 UK. Yahad-In Unum archives. Trip No. 48 UK. Witness No. 2198 UK. Yahad-In Unum archives. Trip No. 48 UK. Witness No. 2199 UK. Yahad-In Unum archives. Trip No. 48 UK. Witness No. 2200 UK. Yahad-In Unum archives. Trip No. 48 UK. Witness No. 2215 UK. Yahad-In Unum archives. Trip No. U09 UK. Witness No. 305 UK. Yahad-In Unum archives. Trip No. U09 UK. Witness No. 311 UK. Yahad-In Unum archives. Trip No. U09 UK. Witness No. 312 UK. Yahad-In Unum archives. Trip No. U09 UK. Witness No. 314 UK. Yahad-In Unum archives. Trip No. U09 UK. Witness No. 320 UK. Yahad-In Unum archives. Trip No. U09 UK. Witness No. 321 UK. Yahad-In Unum archives. Trip No. U09 UK. Witness No. 373 UK.

\section{References}

Al'tman, I. (2002). Zhertvy nenavisti: Kholokost v SSSR 1941-1945 gg. Kovcheg.

Chausovskiŭ, Ė. (2018). Vospominaniia o Bobrovom Kute. Evrěskie zemledel'cheskie kolonii IUga Ukrainy i Kryma. http://evkol.ucoz.com/e_chausovsky.htm

David-Fox, M., Holquist, P., \& Martin, A. M. (2014). The Holocaust in the East: Local perpetrators and Soviet responses. University of Pittsburgh Press.

Dekel-Chen, J. (2005). Farming the red land: Jewish agricultural colonization and local soviet power, 1924-1941. Yale University Press. https://doi.org/10.12987/ yale/9780300103311.001.0001

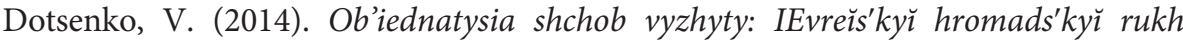
$v$ Ukraïni (60-ti rr. XIX st. - 30-ti rr. XX st.). Nilan.

Gesin, M. (2003). Holocaust: The reality of genocide in Southern Ukraine. University Microfilms International.

Gitelman, Z. (1994). Soviet reactions on the Holocaust. In L. Dobroszycki \& J. S. Gurock (Eds.), The Holocaust in the Soviet Union: Studies and sources on the destruction of the Jews in the Nazi-occupied territories of the USSR, 1941-1945 (pp. 3-28). Routledge. https://doi.org/10.4324/9781315288130

Hilberg, R. (1992). Perpetrators, victims, bystanders: The Jewish catastrophe 1933-1945. Harper Collins.

IAkubova, L. (2003). Polityka ahraryzatsiï ievreŭstva: Sotsial'ni ta ekonomichni naslidky (20-ti - pochatok 30-kh rr. XX st.). Problemy istoriï Ukraïny: Fakty, sudzhennia, poshuki, 2003(10), 178-208.

IAkubova, L. (2010). Natsional'ne administratyvno-terytorial'ne budivnytstvo v USRR/ URSR v 1924-1940. Problemy istorii Ukraïny: Fakti, sudzhennia, poshuki. http:// www.history.org.ua/?termin=Natsionalni_rajony 
Kalinin, M., \& Smidovich, P. (1927). O zemel'nom ustroǔstve trudiashchikhsia evreev v SSSR. KOMZET.

Kalinindorf. (1988). In Ėlektronnaia evrĕ̌skaia èntsiklopediia. https://eleven.co.il/ jews-of-russia/life-in-ussr/11932/

Kalinindorf. (2019). Yad Vashem. https://www.yadvashem.org/untoldstories/ database/index.asp?cid=566

Kaparulin, I. (2018). Epistoliarna spadshchyna Illi Erenburha ta problema (ne) povernennia evakurovanykh ievrë̈v Kalinindorfa (Kalinins'koho) pislia Holokostu. Problemy istorï̈ Holokostu: Ukraïns'kyı̆ vymir, 10, 189-204.

Kaparulin, I. (2019). Holokost ievrë̈v-ahrarï̈v Khersonshchyny. Holokost i suchasnist', 2019(1[17]), 31-47.

Khanin, V. (Ed.). (2016). Documents on Ukrainian Jewish identity and emigration, 1944-1990. Routledge. https://doi.org/10.4324/9780203044902

Khonihsman, I. (1994). Kolektyvizatsiia, holodomor i zanepad ievrěs'koho zemlerobstva v Ukraïni. Ukraïns'kyĭ istorychnyı̆ zhurnal, 1994(2), 66-75.

Korohods'kyı̆, I. (2013). Holod u ievreı̌s'kykh zemlerobs'kykh koloniiakh Ukraïny (1932-1933 rr.): Istoriohrafiia problemy. Storinky istorii: Zbirnyk naukovykh prats', 2013(36), 116-123.

Kostyrchenko, G. (2010). Stalin protiv “kosmopolitov": Vlast' i evreǔskaia intelligentsiia $v$ SSSR. Rossiǔskaia politicheskaia èntsiklopediia.

Kovba, Z., \& Prokhorova, A. (2018, January 19). Arkadiǔ Vaŭspapir: Ostanniǔ iz Sobibora. Istorychna Pravda. https://www.istpravda.com.ua/articles/5a6127164c347/

Krichevskaia, R. (2017). Tragediia v Bobrovom Kute. Association of Concentration Camp and Ghetto Survivors in Israel. https://www.netzulim.org/R/OrgR/ Articles/Stories/Krichevski01.html

Kruglov, A., Umanskiı̌, A., \& Shchupak, I. (2016). Kholokost v Ukraine: Reı̌khskomissariat "Ukraina”, Gubernatorstvo "Transnistriia”. Ukrainskiì institut izucheniia Kholokosta "Tkuma".

Lauer, V. (2010). Tvorennia natsysts'koï imperiïta Holokostv Ukrä̈ni. Zovnishtorhvydav Ukraïny; Ukraïns'kyı̌ tsentr vyvchennia istoriï Holokostu.

Levi, P. (1989). The drowned and the saved. Schocken Books.

Maksymenko, S. (2008). Zahal'na psykholohiia: Navchal'ny̌ posibnyk (3rd ed.). TSentr uchbovoï literatury.Melnyk, O. (2004). Behind the frontlines: War, genocide and identity in the Kherson Region of Ukraine, 1941-1944 [Unpublished master's thesis]. University of Alberta.

Mitsel', M. (2012). "Posledniaia glava": Agro-Dzhořnt v gody Bol'shogo terrora. Dukh i Litera.

Modievskiŭ, S. (1999). Na khersonskol̆ ulitse. Khesed Shmuel.

Modievskiŭ, S. (2003a). Evrei Khersonshchiny. Khesed Shmuel.

Modievskiü, S. (2003b). Vmeste 225 let. Khesed Shmuel.

Modievskiŭ, S. (2006). V poiskakh utrachennogo: "Liudi i sud'by". Khesed Shmuel.

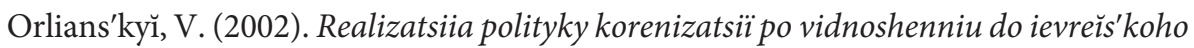
naselennia Pivdnia Ukraïny v 1920-1930-ti rr. Dnipropetrovkyı̆ derzhavnyı̆ universytet. 


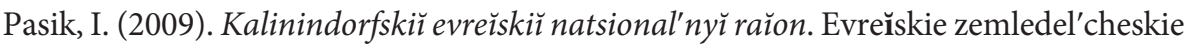
kolonii IUga Ukrainy i Kryma. http://evkol.ucoz.com/kalinindorf.htm

Pasik, I. (2015). Katastrofa evreı̌skogo krest'ianstva IUga Ukrainy i Kryma. Evreŭskie zemledel'cheskie kolonii IUga Ukrainy i Kryma. http://evkol.ucoz.com/colony_ holocaust.htm

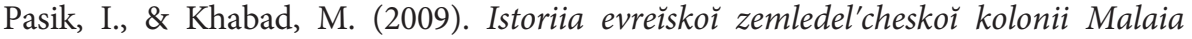
Seĭdemenukha. Evreǐskie zemledel'cheskie kolonii IUga Ukrainy i Kryma. http:// evkol.ucoz.com/m_seydemenukha.htm

Rozenberg, R. (n.d.). Interview 43387. Visual History Archive. USC Shoah Foundation Institute. United States Holocaust Memorial Museum. https://vhaonline.usc.edu

Shchukin, V. (2012). Tragicheskaia khronika Kholokosta na zemliakh Nikolaevskoŭ oblasti. In M. Gol'denberg (Ed.), Sud'by evreev Nikolaevshchiny v period Velikor Otechestvennoĭ voĭny 1941-1945 gg. (pp. 48-86). P. N. Shamraĭ.

Shchukin, V., \& Pavliuk, A. (2016). Evrĕ̌skie zemledel'cheskie kolonii Khersonskŏ gubernii (XIX - nachalo XX vv.): Ocherki istorii. P. N. Shamraŭ.

Shklovskil̆, V. (1990). Sentimental'noe puteshestvie. Novosti.

Shytiuk, M., \& Suhats'ka, N. (2008). Henotsid proty ievrë̈v Pivdennoï Ukraïny v roky nimets'ko-rumuns'koï okupatsiï (1941-1944 rr.). [n.p.].

Tartakovskii, D. (n.d.). Interview 47294. Visual History Archive. USC Shoah Foundation Institute. United States Holocaust Memorial Museum. https://vhaonline.usc.edu

Tashlắ, L. (2018). Zasudzheni do smertnoï kary (do pytannia provedennia u Mykolaïvs'komu rehioni prymusovoï kolektyvizatsiï ta khlibozahotivel', rozkurkulennia zamozhnykh ievreǐs'kykh rodyn). In M. Shytiuk (Ed.), Istorychni midrashi Pivnichnoho Prychornomor'ia (Vol. 7/2, pp. 197-203). Typohrafiia Shamraŭ.

Tron'ko, P. (Ed.). (1982). Istoriia gorodov i sel Ukrainskoŭ SSR: V 26 t.: Khersonskaia oblast'. Glavnaia redaktsiia Ukrainskoĭ sovetskoĭ èntsikopedii.

Venher, A., \& Kakovkina, O. (2014). IEvreǐs'ka ahrarna spil'nota Pivdnia Ukraïny: Hospodars'ka ta sotsiokul'turna adaptatsiia. In A. Podol's'kyı (Ed.), IEvre ̌s' $k a$ natsional'na spil'nota $v$ konteksti intehratsiï ukrä̈ns'koho suspil'stva (pp. 68-114). IPiEND im. I. F. Kurasa NAN Ukraïny.

Venok na mogily muchenikov. (2003). In V. Lebed' (Ed.), Kniga Skorbi Ukrainy: Khersonskaia oblast'. Oldi-plius.

Zeltser, A. (2018). Unwelcome memory: Holocaust monuments in the Soviet Union. Yad Vashem Publications.

ZHurba, M., \& Dotsenko, V. (2005). Shestykutna zirka nad polem: ZHyttia i smert' ievreı̌s'koho zemleoblashtuvannia v Ukraïni (20-30-ti roky XX stolittia). MP Lesia.

Zlochynstva nimets'ko-fashysts'kykh zaharbnykiv na Khersonshchyni (dokumenty i materiali). (1948). Naddniprianska pravda. 


\section{Голокост на Півдні України: реакція урятованих євреїв Калініндорфа після німецької окупації. Анотація}

На основі архівних документів, опублікованих і неопублікованих матеріалівусноїісторії, висвітлюється Голокост в Калініндорфському районі (території сучасних Херсонської та Миколаївської областей) та реакція урятованих євреїв після повернення з евакуації та фронту. На прикладі окремих випадків наведено варіанти поведінки та адаптації євреїв до післявоєнних умов життя. Історичним фоном виступає середина 1940-х рр. як період посилення антисемітських настроїв у суспільстві та партійній верхівці. Відзначається, як повернення євреїв до попереднього життєвого укладу в сільській місцевості, так і неприйняття нових умов і зміна місця проживання. Прослідковано формування традиції єврейської общини із проведення комеморативних практик в місцях масових розстрілів євреїв.

Ключові слова: Голокост, Україна, Херсонщина, єврейські аграрні поселення, німецька окупація.

\section{Holokaust na Ukrainie Południowej. Reakcje ocalałych Żydów dystryktu Kalinindorf po niemieckiej okupacji}

Artykuł bazuje na dokumentacji archiwalnej, opublikowanych i nieopublikowanych relacjach historii mówionej, i stanowi zarys problemu Holokaustu w dystrykcie Kalinindorf (terytorium dzisiejszych obwodów chersońskiego i mikołajowskiego), ukazuje również reakcje ocalałych Żydów po powrocie z frontu i ewakuacji. Na przykładzie poszczególnych przypadków artykuł prezentuje różne zachowania i typy adaptacji Żydów do życia w powojennych warunkach. Tło historyczne stanowi połowa lat 40. XX wieku, jako okres wzmocnienia nastrojów antysemickich w społeczeństwie i wśród przywódców partyjnych. Artykuł opisuje zarówno powrót Żydów do przedwojennego sposobu życia na terenach wiejskich, jak i ich niechęć do nowych warunków i nowego miejsca osiedlenia. Prezentuje również badania nad kształtowaniem się wśród 
społeczności żydowskich tradycji praktyk upamiętniających w miejscach masowej eksterminacji.

Słowa kluczowe: Holokaust, Ukraina, region chersoński, żydowskie osadnictwo rolnicze, okupacja niemiecka.

Przekład z języka ukraińskiego

Olha Tkachenko

\section{Note}

Yurii Kaparulin, Raphael Lemkin Center for Genocide Studies, Department of Public and International Law and Law Enforcement, Kherson State University, Kherson

kaparulin.ksu@gmail.com

The preparation of this article was self-funded by the author.

No competing interests have been declared.

\section{Publication History}

Received: 2019-11-18; Accepted: 2020-12-04; Published: 2020-12-31 